\title{
THE SOUTH CHINA SEA ARBITRATION: THE DECISION AND ITS IMPLICATIONS ON THE SOVEREIGNTY CLAIMS OF CHINA AND THE PHILIPPINES
}

\author{
Zhao Yan Lee*
}

\begin{abstract}
The South China Sea Arbitration which has taken place recently with its final decision published in July 2016 was an action initiated by the Philippines against the People's Republic of China in an attempt to oppose the latter's claims of 'historical rights' in various maritime features in the South China Sea. The panel was constituted under Annex VII of the United Nations Convention on the Law of the Sea. The Chinese Government opposed the constitution, admissibility and ruling of the entire arbitration. It has since put forward many counter claims to refute the validity of the decision reached. China's primary concern inevitably lies with the implications of the decision on the 'Nine-Dash Line', a historic graphical boundary line that has appeared in the Chinese national atlas as early as 1914. This article will qualitatively dissect the decisions made by the arbitral tribunal from a historical perspective, taking into account diplomatic correspondences and authoritative theories in public international law. Ultimately, this article aims to ascertain the implications of the arbitral rulings on the claims of sovereignty of both countries, which remain the terminal concern of the international community. It will be observed, that the ruling, albeit shrouded in irregularities, has posed irreversible impacts on the situation of the South China Sea saga.
\end{abstract}

Keywords: South China Sea, arbitration, United Nations Convention on the Law of the Sea, China

* LL.B Hons (Cardiff University); LL.M (University of Malaya); Lecturer of Law, Tunku Abdul Rahman University College. Email: leezy@tarc.edu.my 


\title{
TIMBANGTARA LAUT CHINA SELATAN: KEPUTUSAN DAN IMPLIKASI TERHADAP TUNTUTAN KEDAULATAN OLEH CHINA DAN FILIPINA
}

\begin{abstract}
ABSTRAK
Timbangtara Laut China Selatan yang telah diadakan baru-baru ini adalah satu tindakan yang dimulakan oleh Filipina terhadap China dalam usaha menentang tuntutan 'hak kesejarahannya' dalam perbagai ciri-ciri maritim di Laut China Selatan. Panel dibentuk melalui Annex VII of the United Nations Convention on the Law of the Sea. Kerajaan China menentang perlembagaan keboleh terimaan dan keputusan seluruh timbangtara tersebut. Kebimbangan China bersandarkan kepada implikasi keputusan 'Nine Dash Line', yang merupakan suatu garis sempadan grafik bersejarah seawal 1914. Makalah ini akan merungkai secara kualitatif keputusankeputusan tribunal timbangtara dari perspektif sejarah, mengambilkira surat-menyurat diplomatik dan teori-teori berwibawa dalam undangundang antarabangsa awam. Akhirnya, makalah ini bertujuan untuk menjelaskan implikasi-implikasi keputusan timbangtara terhadap tuntutan kedaulatan kedua-dua negara, yang terus menjadi kebimbangan masyarakat antarabangsa. Walaupun terdapat kecelaruan dalam keputusan, ia telah memberi impak yang tidak dapat dipulihkan dalam konflik Laut China Selatan.
\end{abstract}

Kata kunci: Laut China Selatan, timbangtara, United Nations Convention on the Law of the Sea, China

\section{INTRODUCTION}

The South China Sea Arbitration was initiated by the Philippines and it has delivered decisions that are rather influential to the regional future sovereignty disputes, despite the fact that the arbitral tribunal has attempted its best to obviate involvement in sovereignty issues. ${ }^{1}$ It will, however, be seen that the tribunal ruling results in a direct impact on the sovereignty claims of both countries in terms of their merits. It will also be observed expediently that the tribunal's formation was not procedurally uncontroversial, mainly owing to the fact that the tribunal

${ }^{1}$ The Republic of Philippines v. The People's Republic of China [2015] PCA Case No. 2013-19, Awards on Jurisdiction and Admissibility, para 150. 
has self-determined its jurisdiction in a case that may very well end in vast implications on sovereignty.

In this article, the discussion repositions the readers in the prearbitration period, in which the tribunal has to self-determine the extent of its jurisdiction to prevent direct encroachments with international sovereignty issues, of which it is not under legitimate authority to deal with. The Chinese has chosen to remain unrepresented throughout the arbitration until the conclusion of the arbitration on $29^{\text {th }}$ October $2015 .^{2}$ They have earlier issued official oppositions to the jurisdiction of the arbitral tribunal which have mostly highlighted their conservative position that the tribunal should not be empowered to deal with sovereignty issues. ${ }^{3}$

To truly assess the viability of the arbitral tribunal's opinions on its own jurisdiction, it would be essential to grasp the context of SinoFilipino diplomatic situations in regards to NDL before the commencement of arbitration. This would be the first part of this section. Subsequently, the section will venture into the following two key issues which the tribunal itself has addressed before it decided to admit the case:

1. Excludability of tribunal's jurisdiction in the "Declaration in the Code of Conduct" 4

\section{The Exhaustion of Diplomatic Negotiations}

Due to the highly technical and sophisticated layout of the South China Sea's geography, various nations that are partaking in the dispute for sovereignty or any form of maritime entitlements have

2 Ibid, p 2.

${ }^{3}$ Chinese Ministry of Foreign Affairs, "Position Paper of the Government of the People's Republic of China on the Matter of Jurisdiction in the South China Sea Arbitration Initiated by the Republic of the Philippines" (2014) para 17 http://www.fmprc.gov.cn/mfa_eng/zxxx_662805/t1217147.shtml accessed: 21/4/2017.

${ }^{4}$ A convention between littoral states to the disputed South China Sea disputed area which required state parties to "resolve their territorial and jurisdictional disputes by peaceful means through friendly consultations and negotiations in accordance with principles of international law, see Art 4 of DCC. 
been engaged in dynamic negotiations in regards to the most appropriate way to resolve the issues. In pursuit of the common objective to attain better resolutions, China and all the involved South East Asian countries affirmed on November 2002 in the Declaration on the Code of Conduct (DCC) that they would:

“...resolve their territorial and jurisdictional disputes by peaceful means ... through friendly consultations and negotiations by sovereign States directly concerned, in accordance with universally recognized principles of international law, including the 1982 Convention on the Law of the Sea"5

Noteworthy to highlight is that all the countries that have competing claims in the South China Sea are parties to the above declaration, making it a seemingly firm instrument in upholding peaceful diplomatic settlements in the region. ${ }^{6}$ To further buttress the wishes to undergo only diplomatic settlements, without a third party's interference, the government of China has made a supplemental declaration on $25^{\text {th }}$ August 2006 that it rejected the compulsory dispute settlement procedures under Part XV: Section 2 of the United Nations Convention on the Law of the Sea (UNCLOS), which takes place upon the failure of parties in a dispute regarding law of the sea to choose a mutual forum.

Article 287 of the convention reads:

“(1) When signing, ratifying or acceding to this Convention or at any time thereafter, a State shall be free to choose, by means of a written declaration, one or more of the following means for the settlement of disputes concerning the interpretation or application of this Convention:

(a) the International Tribunal for the Law of the Sea established in accordance with Annex VI;

(b) the International Court of Justice;

(c) an arbitral tribunal constituted in accordance with Annex VII; (emphasis added)

${ }^{5}$ Declaration on the Code of Conduct (DCC), para 4.

${ }^{6}$ Position Paper (n 3) para 35. 
(d) a special arbitral tribunal constituted in accordance with Annex VIII for one or more of the categories of disputes specified therein."

Its subsection (3), on the other hand, reads:

"A State Party, which is a party to a dispute not covered by a declaration in force, shall be deemed to have accepted arbitration in accordance with Annex VII."

This subsection is the key provision that sets out compulsory dispute settlement mechanism under the UNCLOS. China has invoked their power to make such exception under Article 298 of the UNCLOS. ${ }^{7}$ The article empowers state parties to the convention to declare exceptions for the foregoing compulsory dispute settlement procedures for certain categories of disputes, most relevant in the present case of which would be history bays and titles. ${ }^{8}$

After the issuance of the 2006 Declaration, there was an 'understanding' statement issued by the Philippines which has committed the country to accept the position of China on this issue. However, in $22^{\text {nd }}$ January 2013, the Philippines have decided to initiate arbitration under Annex VII of the UNCLOS in view to resolve a dispute over respective parties" "entitlements" and the legality of Chinese activities in the South China Sea. ${ }^{9}$ The Philippines have made a total of 14 submissions before the tribunal. The main scopes of the Filipino's claim are three-pronged, and they are centred on:

1. The viability of historic rights of the Nine Dash Line concept

2. The characterisation of hundreds of maritime features within South China Sea in accordance with the UNCLOS

3. The Chinese violation of the obligations under UNCLOS by interfering with Filipino sovereignty through fishing and construction activities ${ }^{10}$

${ }^{7}$ Article 298, UNCLOS.

${ }^{8}$ See: Article 298(1)(a)(i), UNCLOS.

${ }^{9}$ Philippines $v$. China (n 1) para 11.

${ }^{10}$ Ibid, para 4-6. 
The initiation of arbitral procedures and the content of the claims were sternly protested by the Chinese on several grounds. Firstly, China was adamant that an Annex VII tribunal barely enjoys any jurisdiction over application and interpretation of the UNCLOS because it has not obtained consent from China. China is of the view that the power of the tribunal in deciding these issues will only be legitimate after the sovereignty issues are determined. China also protested against the selective approach of Philippines in choosing only a portion of the claimed area of Chinese to submit for the arbitral tribunal to determine their ability to generate maritime zones. ${ }^{11}$

The discussion would be addressing the substantive aspects of the Filipino claims in section II. In this section, however, attention must be paid to the jurisdictional issues that surround the tribunal in delivering decisions which contain grave prospects of influencing sovereignty issues in the region.

\section{ADMISSIBILITY OF THE ARBITRAL CLAIM}

\section{Excludability of tribunal's jurisdiction in the Declaration on the Code of Conduct}

The DCC, was a key basis behind the Chinese protests of Filipino's unexpected arbitration move. The DCC has codified state parties' consensus to resolve South China Sea dispute via peaceful means. And this shall be done through "friendly consultations and negotiations." 12 The actions on part of Philippines in engaging the Annex VII arbitration is a permission for a third party to interfere in the dispute, inevitably.

In the tribunal's views, the DCC did not obstruct any jurisdiction that could be exercised by it because of three reasons. Firstly, the DCC does not have a legally binding status; it was a political declaration which is conducive for diplomatic purposes but not intended to have a hard law nature. Secondly, the tribunal also noted that the friendly negotiations

\footnotetext{
${ }^{11}$ Position Paper (n 3) para 22.

12 Declaration on the Code of Conduct (DCC), para 4.
} 
and consultations contemplated by the DCC have not resulted in any constructive outcome for years. Thirdly, the DCC has not been phrased in a way that provides an exclusion of all other means of dispute settlement mechanisms. ${ }^{13}$

The first rationale put forward by the tribunal was in reality a matter of priority of competing dispute settlement procedures in the law of the sea. The key question to address here is under what kind of circumstances the UNCLOS's compulsory dispute settlement procedures will take priority over its counterparts contained in other international instruments of which states have entered into alongside UNCLOS. ${ }^{14}$

This question was on the main agendas of the International Tribunal for the Law of the Sea (hereinafter "ITLOS") in the Southern Bluefin Tuna Case.${ }^{15}$ In this case, Australia and New Zealand have raised a complaint against Japan on the issue of conservation of Southern Bluefin Tuna under the Convention on the Conservation of the Southern Bluefin Tuna 1993. A tribunal was constituted under Annex VII of the UNCLOS as the parties have failed to reach consensus on the choice of forum for the dispute. ${ }^{16}$

Similarly, the Japanese protested against the jurisdiction of the tribunal for the case, basing their opposition in Article 281 of the UNCLOS, which reads:

(1) If the States Parties which are parties to a dispute concerning the interpretation or application of this Convention have agreed to seek settlement of the dispute by a peaceful means of their own choice, the procedures provided for in this Part apply only where no settlement has been reached by recourse to such means and the agreement between the parties does not exclude any further procedure.

${ }^{13}$ Philippines v. China, para 218-229.

14 Schwebel S, "Justice in International Law: Further Selected Writings" (Cambridge University Press 2011), 270.

15 Southern Bluefin Tuna (New Zealand / Australia v. Japan): Awards on Jurisdiction and Admissibility (4 ${ }^{\text {th }}$ August 2000) .

${ }^{16}$ Sturtz L, "Southern Bluefin Tuna Case: Australia and New Zealand v. Japan" 28 Ecology Law Quarterly 461-462. 
In simpler terminology, this provision means that if states have chosen to negotiate about a particular dispute, they could only resort to compulsory dispute settlement procedures if no settlement has been reached in the negotiations. In the 1993 Convention, another arbitral dispute settlement procedure was prescribed.

Australia and New Zealand, in this case, had approached the ITLOS in the first instance in order to apply for an interim measures. In agreement to grant the wishes of the both of the nations, the ITLOS held that it does reserve jurisdiction over the case, not withstanding that there is a competing clause in the 1993 Convention. The Japanese objections were rejected on the ground that the 1993 Convention did not specifically exclude the involvement of UNCLOS dispute settlement bodies. ${ }^{17}$

The ITLOS had the base of its ruling on the concept of: “...presumption of parallelism of compromissory clauses."18

Besides, the tribunal was also adamant that it remained a common phenomenon in international law for a particular dispute to fall within the purview of two or more treaties. ${ }^{19}$

However, when the case reached the Annex VII Tribunal (hereinafter "SBT tribunal"), another opinion was reached in regards to its own jurisdiction. The SBT Tribunal held that the interpretation of the relevant provisions in the 1993 Convention shows that it is conclusive in ruling out the dispute settlement mechanisms under UNCLOS and that consensual nature of all parties to any arbitration that might arise in the subject matter. ${ }^{20}$

"...in the view of the Tribunal, the absence of an express exclusion of any procedure in Article 16 is not decisive. Article 16(1) requires the parties to "consult among themselves with a view to having the dispute resolved by negotiation, inquiry, mediation, conciliation, arbitration,

17 Southern Bluefin Tuna (New Zealand / Australia v. Japan): Provisional Measures (1999) ITLOS Case No. 3.

${ }^{18}$ Ibid.

${ }^{19}$ Schwebel S, "The Southern Bluefin Tuna Case" in Ando N, McWhinney \& Wolfrum R, "Liber Amicorum Judge Shigeru Oda" (Kluwer 2002): 743-748.

${ }^{20}$ Southern Bluefin Tuna, para 57. 
judicial settlement or other peaceful means of their own choice." Article 16(2), in its first clause, directs the referral of a dispute not resolved by any of the above listed means of the parties' "own choice" for settlement" 21

The South China Sea Arbitral Tribunal (hereinafter "SAT") has followed the approach of ITLOS in Southern Bluefin Tuna Case, in holding that in order for DCC to legally exclude UNCLOS dispute settlement procedures, an express provision with the same effect must be contained within the declaration. A plain reading of the DCC would also demonstrate that the parties have not been able to agree on the exclusion of any dispute settlement procedures. ${ }^{22}$

The tribunal has held that:

"As stated above, the Parties disagree on whether an express exclusion is required. The Philippines argues that the intent to exclude further procedures under the Convention must be evident from the terms of the agreement itself. China considers an express exclusion unnecessary and subscribes to the view of the majority of the Annex VII tribunal in Southern Bluefin Tuna. The Tribunal considers that the better view is that Article 281 requires some clear statement of exclusion of further procedures. This is supported by the text and context of Article 281 and by the structure and overall purpose of the Convention. The Tribunal thus shares the views of ITLOS in its provisional measures orders in the Southern Bluefin Tuna and MOX Plant cases, as well as the separate opinion of Judge Keith in Southern Bluefin Tuna...."23

However, to characterise express exclusion as a firm requirement in international law to exclude UNCLOS dispute settlement procedures is perhaps misleading and incorrect. This is because it is the state parties' intention to the third treaty that matters at the end of the day. It would be absurd to irrebuttably presume that UNCLOS procedures would apply so far as the express exclusion is absent, even though it would go against the wishes of the state parties.

21 Ibid.

${ }^{22}$ See in general, $D C C$.

${ }^{23}$ Philippines v. China, para 223. 


\section{The Exhaustion of Diplomatic Negotiations}

Another key issue that might very well obstruct the exercise of jurisdiction by the tribunal is the exhaustion of diplomatic means of dispute settlements between Philippines and China, which has the basis in the UNCLOS itself. ${ }^{24}$ The clear principle in UNCLOS is that, if parties have committed themselves to a mode of dispute settlement, including diplomatic negotiations and consultations, then before the exhaustion of these modes, the compulsory procedure under Annex VII could not apply. This is also the basis of Japanese counterclaims in Southern Bluefin Tuna Case. ${ }^{25}$

In the tribunal's words, the Philippines have adduced submissions which dealt with a rather different scope of questions compared to those which have been addressed during parties' negotiations and consultations. This, according to the tribunal, constitutes no bar to the Filipino's claims, because under international law, only the subject matter of a claim has to correlate with that of the negotiation that took place prior to the arbitration, they do not necessarily have to be exactly similar. ${ }^{26}$ The tribunal has made a reference to an authoritative statement of the ICJ for the questions of scoping of claims addressed in Georgia v Russia:

"Concerning the substance of negotiations, the Court has accepted that the absence of an express reference to the treaty in question does not bar the invocation of the compromissory clause to establish jurisdiction... However, to meet the precondition of negotiation in the

${ }^{24}$ Pham H, "Case: Philippines v. China: The South China Sea

Finally Meets International Law" 16 Chicago-Kent Journal of International and Comparative Law: 3.

${ }^{25}$ Southern Bluefin Tuna (New Zealand / Australia v. Japan): Provisional Measures (1999)ITLOS Case No. 3.

${ }^{26}$ Scott G \& Carr C, "The ICJ and Compulsory Jurisdiction: The Case for Closing the Clause" (1987) 81 The American Journal of International Law 5776. 
compromissory clause of a treaty, these negotiations must relate to the subject - matter of the treaty containing the compromissory clause." 27

In addition to that, the tribunal highlighted that it remained unnecessary for the Philippines to sustain their efforts in conducting diplomatic negotiations with China when they have, albeit on a rather subjective standpoint, considered that the possibility of a diplomatic means to settle the dispute has been exhausted. Quoting the ITLOS in Land Reclamation by Singapore in and around the Straits of Johor, ${ }^{28}$ it held that:

"a State Party is not obliged to pursue procedures under Part XV, Section 1, of the Convention when it concludes that the possibilities of settlement have been exhausted." Moreover, even an obligation to negotiate "does not imply an obligation to reach an agreement," and "the States concerned ... . are in the best position to judge as to political reasons which may prevent the settlement of a given dispute by diplomatic negotiation." 29

Hence, the tribunal held that since the Philippines are of the opinion that they have exhausted all means by negotiations and consultations, the admissibility of their initiation of arbitration was not barred. However, several critiques were presented for the tribunal's rulings at this point.

Firstly, the tribunal would seem to have taken the stance on the negotiation requirement as a precondition for the establishment of itself rather lightly. It is of common understanding that the NDL reserves mostly of illustrative values over probative values. ${ }^{30}$ In which case, the Chinese claims of sovereignty in the NDL were most communicated via diplomatic negotiations and not represented solely by NDL itself. The true evidences behind their sovereignty assertion under the notion of

${ }^{27}$ Application of the International Convention on the Elimination of All Forms of Racial Discrimination (Georgia v. Russian Federation): Preliminary Objections, Judgment, I.C.J. Reports 2011, para 161.

28 Land Reclamation by Singapore in and around the Straits of Johor (2003)ITLOS Case No. 12.

${ }^{29}$ Ibid, para 47.

${ }^{30}$ Dupuy F \& Dupuy P, “A Legal Analysis of China’s Historic Rights Claim In the South China Sea” (2013) 107 American Journal of International Law: 132. 
'historic titles' came solely from diplomatic correspondences. Hence, it is argued that a more objective view of the negotiation requirement is supposedly more appropriate to be adopted by the tribunal in the present case, as opposed to the present, subjective view. ${ }^{31}$ The Permanent Court of International Justice in 1924 held that:

"[The Court] recognises, in fact, that before a dispute can be made the subject of an action at law, its subject matter should have been clearly defined by means of diplomatic negotiations. Nevertheless, in applying this rule, the Court cannot disregard, amongst other considerations, the views of the States concerned, which are in the best position to judge as to political reasons which may prevent the settlement of a given dispute by diplomatic negotiation." 32

Secondly, the tribunal has spent considerable amount of efforts to steer the dispute in line with obligations of state to "exchange views" under Article 283 of the UNCLOS:

"When a dispute arises between States Parties concerning the interpretation or application of this Convention, the parties to the dispute shall proceed expeditiously to an exchange of views regarding its settlement by negotiation or other peaceful means." ${ }^{33}$

In order for the tribunal to have jurisdiction over the matter, it must be proven that the Philippines has exhausted all discussions and negotiations as means to settle their competing claims with China. Unless there has been actual occurrence of some rounds of negotiations, the Philippines could not be said to have legitimately claimed that it has exhausted all possible avenues for negotiations. The notion of exhaustion, however, remains a subject of controversies. No specific scope exists in international law to delineate the timing of real "exhaustion" in

${ }^{31}$ Malek M, "A Legal Assessment of China's Historic Claims in the South China Sea" (2013) 5 Australian Journal of Maritime and Ocean Affairs: 28-36.

${ }^{32}$ Case of the Mavrommatis Palestine Concession (1924) PCIJ No. 6 p 15.

${ }^{33}$ Article 238, UNCLOS. 
negotiation. ${ }^{34}$ The ICJ had two instances, in which they have provided abstract, but supportive, definitions for "exhaustion in negotiation".

In Georgia v. Russia, making reference to authorities since the 1960s, the ICJ held that:

"Manifestly, in the absence of evidence of a genuine attempt to negotiate, the precondition of negotiation is not met. However, where negotiations are attempted or have commenced, the jurisprudence of this Court and of the Permanent Court of International Justice clearly reveals that the precondition of negotiation is met only when there has been a failure of negotiations, or when negotiations have become futile or deadlocked." ${ }^{35}$

In Questions relating to the Obligations to Prosecute or Extradite, the ICJ held that:

"The fact that, as results from the pleadings of the Parties, their basic positions have not subsequently evolved confirms that negotiations did not and could not lead to the settlement of the dispute." 36

Arguably, it is not difficult to observe that the South China Sea situation would satisfy these two requirements. Firstly, regarding whether the negotiations between Philippines and China have become futile or deadlocked, it remains indisputable that the Chinese have unilaterally undertaken actions of fisheries and major construction activities within the NDL even though the negotiations between them and the concerned state parties have not yielded significant consensus on sovereignty. At this point, the usefulness of subsequent negotiations would be in great doubts, since the unilateral actions of the Chinese have demonstrated that they have only desired an outcome springing out of the negotiations, in which they assert indefeasible sovereignty in the NDL.

34 Buzan B, "Negotiating by Consensus: Developments in Technique at the United Nations Conference on the Law of the Sea" (1981) 75 The American Journal of International Law: 324-348.

${ }^{35}$ Application of the International Convention on the Elimination of All Forms of Racial Discrimination (Georgia v. Russian Federation): Preliminary Objections, Judgment, I.C.J. Reports 2011:133.

${ }^{36}$ Questions relating to the Obligations to Prosecute or Extradite (Belgium $v$ Senegal) (2012) ICJ Reports, para 59. 
Secondly, in connection to the criterion on the non-evolution of basic positions of the parties, the South China Sea dispute for years has been stagnant and deficient in progress. Aside from the DCC and series of note verbale exchanges which happened at recent times, no major showcase of states' consensus has been recorded in any of the official documents. Hence, the negotiations which have taken place so far could not improve the positions of the parties to the dispute. Considering the attitude of the Chinese government in taking a rather unilateral, bigoted, course on the matter, the Philippines was not wrong to take the matter for an independent settlement process.

It would then seem that the Philippines has indeed exhausted the negotiation efforts in the face of rather dogged diplomatic behaviours of the Chinese. However, it is unclear whether the amount of time involved in the South China Sea dispute has espoused the exhaustion requirement. ${ }^{37}$ After all, the negotiation process is one which takes a substantial amount of time, especially in regards to issues of national sovereignty. The question remains as to under what threshold should the Sino-Filipino negotiations satisfy in order to render their claims admissible in the jurisdiction of the arbitral tribunal. ${ }^{38}$

The UNCLOS has been explicit in requiring parties to enter into appropriate negotiations for a "reasonable period of time" before they finalise upon the delimitations of their maritime zones. This is reflected in Articles $74 \& 83^{39}$ of the UNCLOS in respects to EEZ and Continental Shelf. The notion of "reasonable period of time" was not specifically assessed in the international law jurisprudence, similarly as in the case of the concept of 'reasonableness' in the Law of Torts. It is generally understood that the ICJ has been relatively lenient in characterising 'reasonableness' in time for negotiations between state parties. For

\footnotetext{
${ }^{37}$ Merrils J, "International Dispute Settlement" $5^{\text {th }}$ edn, (Cambridge University Press 2011): 1.

38 Ibid.

${ }^{39}$ Adopted after the negotiations in the Third United Nations Conference on the Law of the Sea. See, UN, "United Nations Diplomatic Conferences" http://legal.un.org/diplomaticconferences/lawofthesea-1982/lawofthesea1982.html accessed: 30/4/2017.
} 
instance, in Barbados v. Trinidad and Tobago ${ }^{40}$ a quarter of century was held to be a reasonable amount of time to determine the delimitation of maritime zones between the states. In another instance between Bangladesh and India, a 40 years period was recognised as reasonable amount of time for such delimitation. The PCA in this case ruled that:

"The Tribunal notes that the Parties have sought to reach an agreement on the delimitation of their maritime zones in 11 rounds of negotiations since 1974 without success. Although India has suggested that these negotiations were close to agreement, it does not claim that article 283 of the Convention has not been complied with." ${ }^{41}$

the dispute and the battles of diplomacy between the states claiming sovereignty over features in South China Sea really started in very recent times, approximately in the beginning of the $21^{\text {st }}$ century. ${ }^{42}$ Having just a few years, possibly less than a decade of negotiations between state parties in dispute, many have opined that it would be more appropriate for the tribunal to reserve many of the issues dealt with to the interchange between the parties to be able to further uphold the concept of compromises in the law of the sea, rather than to finalise many points of law in haste, as what it did. ${ }^{43}$

Therefore, with reference to this position of international law, so far as the government of Philippines is able to demonstrate proofs that they have entered into negotiations with China before the arbitration takes place, the tribunal's jurisdiction would not be terminated due to deficiency of diplomatic exchanges between parties under Article 283. Moreover, the proofs of negotiation need not show that the Philippines

${ }^{40}$ Arbitration between Barbados and the Republic of Trinidad and Tobago, relating to the delimitation of the exclusive economic zone and the continental shelf between them (11 April 2006) Reports of International Arbitral Awards: Volume XXVII.

${ }^{41}$ The Bay of Bengal Maritime Boundary Arbitration (Bangladesh v. India): Awards (2014) PCA Case No. 383, para 72.

42 JianMing S, “China’s Sovereignty Over South China Sea Islands: A Historical Perspective” (2002) 1 Chinese Journal of International Law: 94.

${ }^{43}$ Pemmaraju S, "The South China Sea Arbitration (The Philippines v. China): Assessment of the Award on Jurisdiction and Admissibility" 15 Chinese Journal of International Law para 32. 
has concluded any consensus or agreements with its Chinese counterparts. For the purposes for discussion, the many exchanges of note verbale, declarations and letters would show that the Chinese and the Filipinos are indeed in the negotiation stage before the arbitration. Nevertheless, the amount of time devoted for such negotiation remained largely in question; in view that international law generally presumes that the amount of time taken for this stage is rather lengthy and considering the prematurity of the South China Sea dispute. The position in relation to whether there is a certain time frame for reasonableness for negotiations between states remains yet to be explored by the ICJ, but it is likely that it would be taking a conservative and generic approach, as in Barbados. ${ }^{44}$

\section{IMPACTS OF THE ARBITRATION}

Having analysed the tribunal's address on several issues in relation to admissibility and jurisdiction, the discussion now turns to assess the merits and impacts of the arbitral awards. The tribunal delivered its decision in favour of Philippines on $12^{\text {th }}$ July 2016. Among their decisions, most notable are the one which declared that the Chinese NDL has no legal value and the Chinese are not entitled to historic rights under it. This is because China has effectively "extinguished" its historic rights to this region by the accession in 1996 to the UNCLOS, ${ }^{45}$ which has specific thresholds for the delimitation of maritime zones.

This has incited fiery reactions among both the Chinese government and citizens. Protests were furiously stirred up in China as the media condemned the decisions of the arbitral tribunal heavily. ${ }^{46}$ China has vowed not to accept any authoritativeness of the decision, despite the fact that it is legally binding in accordance with the UNCLOS. President Xi

${ }^{44}$ For an extensive discussion on diplomatic negotiation in good faith, see Quagliato P, "The Duty to Negotiate in Good Faith" (2008) 50 Journal of Law and Management: 213-225.

${ }^{45}$ Philippines $v$. China (n 1) para 168.

46 Perlez J, “Tribunal Rejects Beijing's Claims in South China Sea” (2016) https://www.nytimes.com/2016/07/13/world/asia/south-china-sea-hague-rulingphilippines.html accessed: 1/5/2017. 
Jin Ping in his statement in reply to the arbitration's outcome was adamant that China is still assertive of its historic rights in the NDL. ${ }^{47}$ The Ministry of Foreign Affairs in China rejected the validity of the decision absolutely. ${ }^{48}$

In this section, the decision of the arbitral tribunal will be assessed from a legal perspective. The key issue to be resolved here is whether the tribunal was correct in making this series of decisions which many have contended that they have almost definite and direct prospects in affecting states' sovereign claims in the South China Sea. The merits and implications of the arbitral tribunal's decision must be re-examined in light with norms, principles and cases of public international law to demonstrate its validity and strength.

It is of no doubt that the arbitral tribunal has held earlier in regards to admissibility and jurisdiction that it will isolate the real issue to determine the object of the claims. In other words, it reserved itself from dealing with issues of sovereignty, which obviously do not fall under its domain until the state parties to the dispute have provided unequivocal consent. ${ }^{49}$ Nevertheless, the end result of the arbitral proceedings which provided the Philippines with victory does not seem to go hand in hand with the very reservation that gave the arbitral tribunal the jurisdiction to produce decisions. ${ }^{50}$ This was sternly criticised by the Chinese legal commentators as well the government. Below, the discussion will highlight the submissions made by the Philippines and the final rulings of the tribunal in regard to them. Subsequently, it shall re-examine the arbitral tribunal's decisions in a total of three highly critical, but nonexhaustive, aspects, from the analysis of the rulings of the tribunal:

1. Defragmenting Philippines' Submissions

2. Consensual Nature Revisited

\footnotetext{
${ }^{47}$ Ibid.

${ }^{48}$ Ibid.

${ }^{49}$ Philippines v. China (n 1) para 150.

${ }^{50}$ SienHo Y, "The South China Sea Arbitration (Philippines v. China): Potential Jurisdictional Obstacles or Objections" (2014) 13 Chinese Journal of International Law: 676.
} 


\section{Historic Rights-Delimitation-Sovereignty Complex}

\section{Submissions and Decisions}

In the arbitration, the Philippines has put forward a total of 15 submissions for the considerations of the tribunal. Below, they will be classified into 5 groups based on their focus:

1. China's rights in the South China Sea should be based on the maritime zones established in the UNCLOS, which comprised of territorial sea, the contiguous zone, the EEZ and the Continental Shelf only. The NDL is a contravention of UNCLOS and it is invalid

2. Mischief Reef, McKennan Reef, Gaven Reef and Subi Reef are submerged features which are not visible during high tides. They are therefore neither rocks nor islands for the purposes of Article 121 of UNCLOS. None of these features are part of the Chinese Continental Shelf, but Mischief and McKennan Reefs are part of the Philippines' Continental Shelf in accordance with UNCLOS. Hence, Chinese activities in the form of construction and occupation of these four features should immediately cease

3. Scarborough Shoal, Cuarteron Reef, Johnson Reef and Fiery Cross Reef should be characterised as "rocks" under Article 121(3) of UNCLOS and they may only general state entitlements to territorial sea. The Chinese have falsely claimed maritime entitlements beyond 12 nautical miles from these features. China should halt their preventive measures for Filipino vessels to extract living resources in waters in the vicinity of Scarborough Shoal and Johnson Reef.

4. According to the UNCLOS, the Philippines would be entitled to a 12 nautical miles territorial sea, a 200 nautical miles EEZ and a continental shelf as measured from its archipelagic baselines. China thus has illegally undergone exploitative activities in Filipino maritime zones and prevented Philippines from exploiting resources from these regions

5. China has unlawfully interfered with Filipino exercise of navigational rights and other rights under the UNCLOS in and 
beyond the Filipino EEZ and they should stop these activities immediately $^{51}$

In response to the submissions by the Philippines, the tribunal delivered its decision on the $12^{\text {th }}$ July 2016 , which could be summed up as the following, in direct correlation with the above grouped submissions:

1. The UNCLOS has superseded any historic right or entitlements. The limits of maritime zones set out therein should be abided by state parties regardless of any claims alongside. Hence, the NDL does not have any basis in the Law of the Sea

2. Mischief Reef - Low Tide Elevation

McKennan Reef - High Tide Feature

Gaven Reef - Low Tide Elevation

Subi Reef - Low Tide Elevation

3. Scarborough Shoal, Cuarteron Reef, Johnson Reef and Fiery Cross Reef are rocks

4. Through the operation of marine surveillance, the Chinese has tolerated and failed to exercise due diligence to prevent Chinese nationals from exploiting living resources in Filipino maritime zones

5. Through marine surveillance and promulgation of the fishing moratorium in the South China Sea during year 2012, China has interfered with the exercise of navigational rights and other rights under UNCLOS in their own EEZ ${ }^{52}$

The decisions reached by the arbitral tribunal were perhaps technically accurate in juxtaposition with principles contained in the UNCLOS. But the circumstances surrounding the climate under which

${ }^{51}$ Michael G, "The Sino-Philippine Arbitration on the South China Sea Disputes: Ineffectiveness of the Award, Inadmissibility of the Claims, and Lack of Jurisdiction, with Special Reference to the Legal Arguments Made by the Philippines in the Hearing on 7-13 July 2015" (2015) 2 China Oceans Law Review: 90.

${ }^{52}$ Ibid 
the decisions were made posed serious questions to the viability of it. Also, much scepticism could be raised in regards to the potential encroachments of the decisions on the issues of sovereignty, which the tribunal itself has been trying to leave at the mercy of diplomacy between the states. Thus, the various dimensions of the decision should be analysed to offer a clearer picture on its accuracy and correctness.

\section{Defragmenting Philippines' Submissions}

Being aware of the lack of jurisdiction of the arbitral tribunal in determination of sovereignty issues, the Philippines had phrased their notification accordingly. It has highlighted that:

"[Philippines] does not seek in this arbitration a determination of which Party enjoys sovereignty over the islands claimed by both of them. Nor does it request a delimitation of any maritime boundaries." ${ }^{53}$

The Philippines has also addressed the issues in regards to the 2006 Chinese Declaration in excluding compulsory dispute settlement procedure, which is in line with their rights under Article 298 of the UNCLOS. It has claimed that its submissions do not correlate with the subject matter contained in the 2006 Declaration.

According to Philippines, their submissions concerned only on:

1. Whether parties' respective rights and obligations in South China Sea are still governed by UNCLOS, in light of the Chinese NDL claim

2. Whether the Chinese NDL is not compliant with UNCLOS

3. Characterisation of various insular features in South China Sea under UNCLOS

4. China's violation of navigational rights and exploitative rights enjoyed by the Philippines ${ }^{54}$

Hence, the Philippines was insistent that:

${ }^{53}$ Note Verbale No. 130211 from the Permanent Mission of the Republic of the Philippines to the UN Secretary-General (Jan 22, 2013) para 7.

54 Ibid, para 39. 
"It follows that the Philippines' claims do not fall within China's Declaration of 25 August 2006, because they do not: concern the interpretation or application of Articles 15, 74 and 83 relating to sea boundary delimitations; involve historic bays or titles within the meaning of the relevant provisions of the Convention; concern military activities or law enforcement activities; or concern matters over which the Security Council is exercising functions assigned to it by the UN Charter." 55

Through this, Philippines has managed to put forward a claim which was seemingly in line with the arbitral tribunal's supposed reservation on sovereignty, but in effect could pose the potential effect of deconstructing the NDL, as a ruling on the status of insular features within the region would determine its abilities in generating maritime zones. In the final section of this study, the "historic rights-delimitation-sovereignty" complex nature of the arbitration would be assessed.

In the language of the Philippines in its notification to initiate arbitration, it has characterised China as sort of a distant state with no relations to the features within the features of South China Sea in question. It has emphasized that the Chinese coast is more than 870 nautical miles away, while the Chinese vessels continued to occupy and seize islands that are extremely far away from the mainland. This would put China in the shoes of a synonymous invader of Filipino islands and features. The failure to regard China as an opposite or adjacent coastal state in the dispute, even if it is just for the purposes of the law, furthermore demonstrated the manipulative phraseology of the notification. In paragraph 1 , it was stated that:

"[Philippines] brings this arbitration against the People's Republic of China to challenge China's claims to areas of the South China Sea and the underlying seabed as far as 870 nautical miles [M] from the nearest Chinese coast, to which China has no entitlement under the 1982 United Nations Convention on the Law of the Sea ("UNCLOS", or "the Convention"), and which, under the Convention, constitute the Philippines' exclusive economic zone and continental shelf." 56

\footnotetext{
55 Ibid, para 40.

${ }^{56}$ Ibid, para 1.
} 
This was also a possible Filipino's strategy in obviating the issue regarding the prospect of features generating maritime zones for the rightful sovereign of them, in order to render the tribunal's jurisdiction unscathed. The quasi-judicial language of Philippines in its notification sought to fragment what was rightfully a sovereignty claim into merely a maritime features classification claim with similar outcome. ${ }^{57}$

The Philippines has also omitted many policy positions of China in regard to the NDL which might be impactful to determine the jurisdiction of the tribunal and the validity of the tribunal's decisions. One of the key issues that was omitted at the very preliminary level was the grouping done at the official level to classify many features in the South China Sea into archipelago units. ${ }^{58}$ China has classified these features into a total of four archipelago units; they are the sensational Nansha Islands, Xisha Islands, Zhongsha Islands and Dongsha Islands. ${ }^{59}$ While having vast potential to result in significant difference in delimitations, these have been ignored altogether in both the filing of Filipino maritime features status claims and the claim against the legitimacy of NDL. For instance, if the grouping of these islands is recognised under international law, they will be generating archipelagic maritime zones, which would be of vast differences as compared to the assessment of them as isolated features.

Many of the island groups have their "borders" in proximity with the Filipino coast, which would definitely give rise to the issues of delimitations if their archipelagic status is upheld. For example, the Scarborough Shoal was located at about 120 nautical miles from the Filipino Luzon Coast. Hence, from this perspective, the Philippines' initiation of the arbitration was indeed based on a distorted course of claims under international law.

${ }^{57}$ In general, see SienHo Y, "The South China Sea Arbitration (Philippines v. China): Potential Jurisdictional Obstacles or Objections" (2014) 13 Chinese Journal of International Law: 676.

${ }^{58}$ Keyuan Z, "The Chinese Traditional Maritime Boundary in the South China Sea and Its Legal Consequences for the Resolution of the Dispute over Spratly Islands" (1999) 14 International Journal of Marine and Coastal Law: 27.

${ }^{59}$ Ibid. 
Thus, the sovereignty issues are the first that should be addressed before an arbitral tribunal or the ICJ itself could rule on the validity of the constitution of archipelagic status of these island groups. Subsequently, if the decision turns out to have failed China (assuming it is the rightful sovereign state over these features) in constituting archipelagic status for these features, they could then be characterised in terms of high-tide / low-tide or rocks / islets / reefs accordingly. ${ }^{60}$ However, if archipelagic status of these features is established, the baselines for archipelagic regions should accordingly be put into place in conformance with Article 47 of the UNCLOS. Delimitation would then be the final act of the tribunal in question. ${ }^{61}$

Although there have been mounting unpredictability and uncertainties associated with the enjoyment of benefits conferred by archipelagos by a coastal state, the fact that it will have a substantial effect on delimitation could not be clearer. From this standpoint, the Philippines has perhaps failed to frame its submissions in a comprehensive way. ${ }^{62}$ This was arguably done in a purposive intent as the Philippines could not be more wary that the tribunal might self-determine that it does not have the jurisdiction to rule on the subject matter. ${ }^{63}$ The orderly course of judgment in principles of the law of the sea also has not been followed.

By its lenient acceptance of the frame proposed by the Philippines, the arbitral tribunal has made a decision which is opposed to ordinary course of international law without sufficient considerations of a wide array of other issues. The point is, sufficient insights have to be afforded to the positions of the parties with regards to the proper mechanics of the characterisation of maritime features, as it is the most preliminary issue to be solved before any submission could move further without the danger of leaving a crucial part of the course of law untouched. Considering the highly political and sensitive nature of the laws of nations, no matter how

\footnotetext{
${ }^{60}$ Michael G (n 51) 90.

${ }^{61}$ Kunoy B, "Agreed Minutes on the Delimitation of the Continental Shelf beyond 200 Nautical Miles between Greenland and Iceland in the Irminger Sea" (2013) 12 Chinese Journal of International Law:124-142.
}

62 Ibid.

63 Sienho (n 57) 663. 
complicated the subjectivity of the views of the states are concerned, it is the role of the tribunal to address them comprehensively in order to avoid a diplomatic crisis from taking place. ${ }^{64}$ The case of Territorial and Maritime Dispute (Nicaragua v. Columbia) ${ }^{65}$ was a great example at this point. In the aftermath of the case, Columbia has publicly withdrawn from the ICJ's jurisdiction and the American Treaty of Pacific Settlement due to the perception of the court's biasness in imposing the views practiced by many states to the Columbian situation, by combining Columbian islands as a single unit, rather than to confer each island a separate enclave domain. ${ }^{66}$

\section{Consensual Nature Revisited}

It is foundational that the UNCLOS does not address issues in association with sovereignty, because it leaves this highly political issue a subject of negotiations. UNCLOS thus does not have any significant content with regards to sovereignty issues. A sovereignty conflict therefore is distinct from the interpretation and application of UNCLOS, the sole matter falling under the jurisdiction of any court or tribunal contemplated by Article 288. ${ }^{67}$ This was proposed by the President of the Conference in response to States' fear about the assumption of tribunals or courts having authority in sovereignty disputes. ${ }^{68}$

It can be reasonably inferred from the language of the UNCLOS that it also does not wish to address issues that are alongside issues of sovereignty. In other words, they are those which share a link with sovereignty issues. In Article 298(1)(a), UNCLOS sets out that states could make exception in regards to the applicability of section 2 but are

${ }^{64}$ Tanaka Y, "Reflections on the Territorial and Maritime Dispute between Nicaragua and Colombia before the International Court of Justice" (2013) 26 Leiden Journal of International Law: 909-931.

${ }^{65}$ Territorial and Maritime Dispute (Nicaragua v. Colombia): Preliminary Objections (2007) I.C.J. Reports, p. 832.

${ }^{66}$ Ibid.

${ }^{67}$ UNCLOS, Article 288.

${ }^{68}$ Sienho (n 57) 689. 
required to submit the disputes for compulsory conciliation procedures. But in following sections, it made clear that:

"....any dispute that necessarily involves the concurrent consideration of any unsettled dispute concerning sovereignty or other rights over continental or insular land territory shall be excluded from such submission. ${ }^{\circ 69}$

The phrase "concurrent consideration of any unsettled dispute concerning sovereignty" demonstrates the spirit of the UNCLOS to avoid any involvement in issues of sovereignty. The materialisation of this section would mean the absence of any issues with direct or indirect association to sovereignty in the contemplation of the convention. ${ }^{70}$

In plain reading, all direct and indirect sovereignty-related issues would not fall under the network of claims capable of being solved by principles contained in the UNCLOS. Article 298 was a caution to prospective forums that could probably choose to adopt a liberal approach in overstepping into the realm of sovereignty. ${ }^{71}$

However, it remains in doubt that whether it is mandatory for the states to opt for an optional exception under Article 298(1)(a) to exempt themselves from giving powers for a tribunal constituted under the UNCLOS to deal with issues of sovereignty. ${ }^{72}$ At this juncture, it is reasonable to suggest that it is not mandatory, since the creation of the provision itself would be unnecessary if states are merely to make a declaration as a formality to ensure that their sovereignty would be protected. ${ }^{73}$ Arguably, the optional declaration mechanism serves to

${ }^{69}$ UNCLOS, Article 298(1)(a)(i) .

${ }^{70}$ Buga I, "Territorial Sovereignty Issues in Maritime Disputes: A Jurisdictional Dilemma for Law of the Sea Tribunals" (2012) 27 International Journal of Marine and Coastal Law: 59-95.

${ }^{71}$ Sienho (n 57) 687.

${ }^{72}$ Rao P, "Delimitation Disputes under the United Nations Convention on the Law of the Sea: Settlement Procedures", in Ndiaye T and Wolfrum R (eds), "Law of the Sea, Environmental Law and Settlement of Disputes: Liber Amicorum Judge Thomas A. Mensah" (2007): 887-892.

${ }^{73}$ Ibid. 
allow states which have entered into disputes on sovereignty issues at the sea a conducive avenue to announce their opting-out position to the rest of the state parties in dispute. In the South China Sea dispute, relevant for present purposes, China has made the declaration.

The principles analysed this far in the UNCLOS could be summed up in the sense that the law of the sea has consent as a core requirement when it is dealing with direct and indirect sovereignty issues at sea. A merged dispute which has sovereignty issues at its root and other issues at its ramifications would as a whole requires state parties' consent in order for a third-party dispute settlement body under the UNCLOS to exercise its jurisdiction legitimately.

Similar conservative approach was taken commonly in the sphere of public international law as well. In the Monetary Gold Case ${ }^{74}$ in which the ICJ has to deal with an issue which it has no jurisdiction: the legal interests of monetary gold, which has passed hands into various nations in the aftermath of World War II. The ICJ held that:

"The Court cannot decide such a dispute without the consent of Albania. But it is not contended by any Party that Albania has given her consent in this case either expressly or by implication. To adjudicate upon the international responsibility of Albania without her consent would run counter to a well-established principle of international law embodied in the Court's Statute, namely, that the Court can only exercise jurisdiction over a State with its consent." $" 75$

It is a relatively simple principle that if the decision on a particular issue would determine the outcome of the main issue that has been presented, state parties to the dispute must be willing to offer their consents to the tribunal to resolve both of the issues if the tribunal is to have jurisdiction over the subsidiary issue. ${ }^{76}$ Similarly, in Nauru $v$. Australia, the ICJ has delivered the following statement:

74 Case of the Monetary Gold Removed from Rome in 1943: Preliminary Question Judgment (1954) ICJ Reports 19.

75 Ibid, 32.

${ }^{76}$ Sienho Y, "Conciliation and the 1982UN Convention on the Law of the Sea" (2013) 44 Ocean Development and International Law :315. 
"In the present case, the determination of the responsibility of New Zealand or the United Kingdom is not a prerequisite for the determination of the responsibility of Australia, the only object of Nauru's claim. Australia, moreover, recognizes that in this case there would not be a determination of the possible responsibility of New Zealand and the United Kingdom previous to the determination of Australia's responsibility. It nonetheless asserts that there would be a simultaneous determination of the responsibility of all three States and argues that, so far as concerns New Zealand and the United Kingdom, such a determination would be equally precluded by the fundamental reasons underlying the Monetary Gold decision."77

It is thus a firm principle in public international law that consents of the states are needed even for subsidiary issues springing from the root issue in order for jurisdiction to be installed validly. The coverage of this principle is not only restrained within the ICJ, as the arbitral tribunal in Larsen v. Hawaii Kingdom ${ }^{78}$ held that:

"In assessing this argument, it needs to be stressed that, in accordance with the agreement between the parties, the Tribunal is called on to apply international law to a dispute of a non-contractual character in which the sovereign rights of a State not a party to the proceedings are clearly called in question. The position in contractual disputes governed by some system of private law and involving the rights of a third party might conceivably be different. But in proceedings such as the present, the Tribunal is not persuaded that the Monetary Gold principle is inapplicable. On the contrary, it can see no reason either of principle or policy for applying any different rule. As the International Court of Justice explained in the Monetary Gold case (ICJ Reports, 1954, at p. 32), an international tribunal may not exercise jurisdiction over a State unless that State has given its consent to the exercise of jurisdiction. That rule applies with at least as much force to the exercise of jurisdiction in international arbitral proceedings. While it is the consent of the parties which brings the arbitration tribunal into existence, such a tribunal, particularly one conducted under the auspices of the Permanent Court of Arbitration, operates within the general confines of public international law and, like the International Court, cannot

77 Certain Phosphate Lands in Nauru (Nauru v. Australia): Preliminary Objections, Judgment (1992) I.C.J. Reports, para 55.

${ }^{78}$ Larsen v. Hawaii Kingdom (1999) PCA 1999-01. 
exercise jurisdiction over a State which is not a party to its proceedings." 79

Hence, the comprehensive and formal institution of consent in the jurisprudence of dispute settlement bodies under the UNCLOS should remain intact and deserving compliance. In the present scenario, it could be observed that the characterization of maritime features in the South China Sea and the validity of NDL in international law are but issues springing from the root claim of sovereignty itself. Any ruling in association with these subsidiary issues would have an impact on the root issue, which itself has yet to find a mutually satisfying forum between Philippines and China. The arbitral proceedings could then be said to have proceeded without fulfilling the strict and necessary consent criteria of international law.

\section{Historic Rights, Sovereignty and Delimitation Complex}

If the objective of the arbitral award was merely geological, in the sense that it only defines the status of the maritime features in question, the outcome of it would be an academic exercise rather than a legal one. China has not been claiming its rights under the UNCLOS with regards to the NDL, but rather, historic rights in the customary international law. Being aware of this fact, the arbitral tribunal stated that this is subject to further discourses, but it nevertheless held that it is entitled to deal with the case even in the face of uncertainties of the scope of claims. ${ }^{80}$

The tribunal has since disregarded the potential overlapping maritime zones which should be able to be determined if there is a certain scope of sovereignty finalised in the NDL and proceeded to rule on the status of maritime features in the South China Sea. If the tribunal still intends to hold firmly to the position it pronounces before it self-determined that it has jurisdiction in the dispute, the series of rulings issued could not interfere with the claims of historic rights and sovereignty from China. ${ }^{81}$ The tribunal has announced its understanding on this fact, since

\footnotetext{
${ }^{79}$ Ibid, para 11.17.

${ }^{80}$ Pemmaraju (n 43) part IX.

${ }^{81}$ See above Part II.
} 
both the notions may be inextricably linked to each other. But at the same note, it held that since historic rights remain a concept that was contemplated by the UNCLOS, it is a subject of interpretation; and the application of it falls under its purview inevitably. ${ }^{82}$

The tribunal, at this point, has omitted the fact that the appearance of the terms in relation to historic rights, historic bays or historic titles is almost definitely in association with exceptions in the UNCLOS. To put it simply, the UNCLOS sought to exclude its coverage on these terms in its salient provisions. Hence, the incorporation of them in the South China Sea Dispute only served as a discouraging factor in terms of the tribunal's exercise of jurisdiction, not a supporting one. The involvement of historic rights in the dispute should prompt and remind the tribunal to rule in isolation of issues that might relate to it, which it has not done so. ${ }^{83}$

The tribunal found that there is a disagreement between China and Philippines in the issue of historic rights and it has decided to deliver its opinions on it with reference to the principles in the UNCLOS. This is perhaps an incorrect approach in law because the UNCLOS has attempted "its best" in avoiding the coverage of historic rights, whereas historic right has the foundation of its notion in customary international law. ${ }^{84}$ In the tribunal's manoeuvres, it would seem that it has accorded a higher status to the UNCLOS as compared to customary international law. ${ }^{85}$ The tribunal has held that:

"Nor is the existence of a dispute concerning the interpretation and application of the Convention vitiated by the fact that China's claimed entitlements appear to be based on an understanding of historic rights existing independently of, and allegedly preserved by, the Convention. The Philippines' position, apparent both in its diplomatic correspondence and in its submissions in these proceedings, is that "UNCLOS supersedes and nullifies any 'historic rights' that may have

\footnotetext{
${ }^{82}$ Philippines v. China (n 1) para 164.

${ }^{83}$ See, for example, UNCLOS Articles 15, 298.

${ }^{84}$ Caminos H \& Molitor M, "Progressive Development of International Law and the Package Deal" (1985) 79 American Journal of International Law: 871-890 ${ }^{85}$ Philippines v. China (n 1) 168.
} 
existed prior to the Convention." This is accordingly not a dispute about the existence of specific historic rights, but rather a dispute about historic rights in the framework of the Convention. A dispute concerning the interaction of the Convention with another instrument or body of law, including the question of whether rights arising under another body of law were or were not preserved by the Convention, is unequivocally a dispute concerning the interpretation and application of the Convention."

The tribunal indisputably was of the opinion that the UNCLOS has superseded any concept of historic rights which are rooted in customary international law. It could then be inferred that the tribunal had the inclination to characterize UNCLOS to have a jus cogens status, which is wholly false. This is because UNCLOS was merely a product of "package-deal" the state parties. The UNCLOS does codify certain degree of state practices with historical importance; it does also codify certain principles of customary international law, but it certainly cannot qualify as jus cogens in its entirety.

In a nutshell, the UNCLOS could not be clearer of its stance in setting the issues of sovereignty and historic rights apart from its reach. The tribunal has erred in its approach in using UNCLOS as a lens to perceive the notion of historic rights, which constituted a perilous move in possibly intervening in the domain of sovereignty, which the tribunal itself sought to dispose of as a preliminary matter.

\section{THE FUTURE OF THE SOUTH CHINA SEA}

The discovery of oil and mineral resources in the South China Sea has prompted unprecedented intensity of Chinese activities and aggressive measures to ensure their dominance over the area. Similarly, the counterparts in ASEAN are attempting their best shot at claiming sovereignty over the area in pursuit of the giant economic incentives it could welcome. However, apart from the avenues to seek legal measures or diplomatic channels to negotiate, they could do little in the face of the increasingly sophisticated strength of the Chinese military. So far, in order to ensure their occupation of the region is effective, they have built a total of seven islands out of reefs and underwater features and places military bases and harbours on top of them. With such installation, the 
Chinese would have the ability to deploy large numbers of submarines, fighters and bombers in the area. ${ }^{86}$

Never in the history has China been so aggressive in taking invasive actions to demonstrate its sovereignty over territories it considered it owns, even in the Third Taiwan Strait Crisis in 1995. The United States has been the main aid behind the smaller nations involved in the dispute, like Vietnam and the Philippines. The techniques used by the Americans so far in balancing the dynamics of South China Sea in the favour of the smaller nations include the freedom of navigation operation, which essentially means the sailing of U.S navy vessels in close proximity with islands which the Americans do not recognise to be under sovereignty of another, and where they are adamant on the applicability of the law on freedom of navigation. ${ }^{87}$

The newly inaugurated President of the United States Donald J. Trump has yet to clarify his administration's position on the South China Sea dispute. It is speculated that his policy priority interest in balancing the stakes between China and the U.S would prompt a more aggressive action compared to the freedom of navigation operation. However, it is imperative for Trump to issue a swift response to the matter since the Chinese have already reached the step where they are building military hardware below and above water. A radar network beneath sea water was also being contemplated by the Chinese. This, if successfully built, would have the ability to diminish stealth operations of U.S submarines. ${ }^{88}$

Trump administration should implement swift and comprehensive strategy in opposition to Beijing to ensure the interests of many ASEAN nations are preserved in the face of Chinese dynamic and aggressive

${ }^{86}$ Layton P, "The Simple Reasons Why South China Sea is Headed for Tragic Troubles" (2016) http://nationalinterest.org/blog/the-buzz/the-simple-reasonswhy-the-south-china-sea-headed-tragic-18633 ?page=2 accessed: 1/6/2017.

${ }^{87}$ Westcott B, "South China Sea: US warship challenges China's claims with first operation under Trump" (2017) http://edition.cnn.com/2017/05/24/politics/south-china-sea-us-mischief-reef/ accessed: 1/6/2017.

${ }^{88}$ Kazianis H, "Trump's Big Mistake in the South China Sea" (2017) http://theweek.com/articles/701749/trumps-big-mistake-south-china-sea accessed: 1/6/2017. 
manoeuvres. If necessary, Mr. Trump could also counteract to Chinese refusal to comply with international law by political measures. In Kazianis' words:

"if Beijing wants to push forward in changing the status quo, America could remind them it has options as well — like a big arms packages to Taiwan, something Taipei has been asking for that would surely rattle Beijing." 89

On the other hand, the Chinese were firm on the inappropriateness of U.S operation in the region. Wang, a policy expert at the China Institute of Contemporary International Relations, opined that:

"While the US insists they have the right to send warships to the disputed waters in the South China Sea, Beijing has always insisted that freedom of navigation should not cover military ships." ${ }^{\circ 0}$

The spokeswoman for the Chinese National People's Congress has made it clear that:

"The overall situation in the South China Sea tends to have improved at the moment and where it is heading will be decided by the US intent [because] American activities in the sea serve as a signpost to some extent." $" 91$

Therefore, the situation and the hostilities in the region would have a substantial portion to deal with American attitude once they have resolved the main issues in the Middle-East. Meanwhile, the Chinese are speeding up on their rate to install military equipments and artificial structures in the area to ensure that they are well prepared for any future U.S actions. It would all depend on the situation and timing of both the parties to determine the direction to which the dispute is heading. ${ }^{92}$

${ }^{89}$ Ibid.

${ }^{90}$ Jiangtao S, "Future of South China Sea disputes depends on Washington, says China's legislature spokeswoman"

(2017)

http://www.scmp.com/news/china/diplomacy-defence/article/2076092/futuresouth-china-sea-disputes-depends-washington-says accessed: 1/6/2017.

${ }^{91}$ Ibid.

${ }^{92}$ Watkins D, "What China has been Building in the South China Sea" (2015) https://www.nytimes.com/interactive/2015/07/30/world/asia/what-china-hasbeen-building-in-the-south-china-sea.html accessed: 1/6/2017. 
The prospect of an ICJ proceeding in regards to the dispute is also in consideration since China has rejected the rulings of the arbitral tribunal in its entirety and its actions have proved such disregard. The legal issues surrounding the dispute are yet to be comprehensively addressed.

\section{CONCLUSION}

The South China Sea arbitration was instituted as an initiative on part of Philippines to declare certain points of law in regard to the NDL. The constitution and the jurisdiction of the arbitral tribunal were unendorsed by the Chinese, which raised serious doubts as to its decision's practical effects. In fact, a study on the arguments put forward by the tribunal in declaring the existence of jurisdiction would show its defects in many ways. In particular, no sufficient discourses have been offered in regards to the realistic exhaustion of diplomatic remedies between Philippines and China, which would render compulsory dispute settlement procedures valid under UNCLOS. There has also been an understatement of compromises which could overtake the tribunal in deciding points of law in relation to sovereignty and delimitation issues.

The substantive scope of the tribunal's awards was also submerged in uncertainties. The fragmentation approach by the Philippines in framing their argument has misled the tribunal into delivering judgments that may have direct consequences on sovereign issues. It is important in the face of delivery of such kind of decisions to first obtain China's consent in order to avoid the prospect of making the situation overly complex, which the tribunal has not done so due to perhaps its failure to comprehend such facts. In constituting its authority to deliver judgments, the tribunal has also falsely acknowledged that historic right was indeed contemplated by the UNCLOS. This resulted in its decisions on issues of historic rights which its jurisdiction actually does not cover. By ruling on historic rights itself, the tribunal has gone a step further from declaratory judgments on maritime features to the delimitation-sovereignty complex of the issue. This move should not be constitutional under the UNCLOS.

The future of the South China Sea dispute remains in vast uncertainties. In the region itself, we have China speeding up its process of occupation through many means, some military. The ASEAN nations have not been able to react effectively because they possess no comparable strength both in the economy and the military. Their only 
resort is their partner in America, the U.S. However, the U.S latest presidential election of Mr. Trump further muddied the position of the U.S in the South China Sea matter, as Trump administration possesses very different beliefs and values compared to its predecessor. It is speculated that Donald Trump would adopt a much stricter position compared to President Obama, the exact scope of which remains unclear.

In a nutshell, the South China Sea dispute is merely at its budding stage and there is still a long journey before the nations involved. The dispute remains one which cannot be resolved solely by legal means, but very much on diplomatic exchanges, negotiations and compromises. The author does not wish to side any state parties to the dispute. However, it should be clear, from the history, that a harmonious situation could only be sustained if there is balance of interests between the states. This would reflect the spirit of public international law. After all, it is the interests that are at stake between the nations when it comes to any type of dispute. Hence, they should form the primary consideration of any adjudicative body or any diplomatic negotiations. In the South China Sea dispute, there should be a fair and just apportionment of these features based on the prospect of interests. 